\title{
Determination of Critical Influencing Factor on pH Stability of Yuxingcao Injection
}

\author{
Xianjun Long1, Bo Liu², Zuren Peng1, Ping Qiu1, Xuechun Yang1, Yuanxiang Yang1, Meili Wang1, \\ Songmao Yin 1 , Xingchu Gong2,3*
}

${ }^{1}$ Hunan Zhenqin Pharmaceutical Group Co., Ltd., Huaihua, China

${ }^{2}$ School of Pharmaceutical Engineering of Traditional Chinese Medicine, Tianjin University of Traditional Chinese Medicine, Tianjin, China

${ }^{3}$ Pharmaceutical Informatics Institute, College of Pharmaceutical Sciences, Zhejiang University, Hangzhou, China

Email: ^gongxingchu@zju.edu.cn

How to cite this paper: Long, X.J., Liu, B., Peng, Z.R., Qiu, P., Yang, X.C., Yang, Y.X., Wang, M.L., Yin, S.M. and Gong, X.C. (2020) Determination of Critical Influencing Factor on $\mathrm{pH}$ Stability of Yuxingcao Injection. Pharmacology \& Pharmacy, 11, 188-195 https://doi.org/10.4236/pp.2020.118017

Received: July 23, 2020

Accepted: August 28, 2020

Published: August 31, 2020

Copyright $\odot 2020$ by author(s) and Scientific Research Publishing Inc. This work is licensed under the Creative Commons Attribution International License (CC BY 4.0).

http://creativecommons.org/licenses/by/4.0/

\section{(c) Open Access}

\begin{abstract}
The change of drug quality of Yuxingcao injection after formulation is considered as one of the causes for adverse reactions. In this study, orthogonal experimental design was used to investigate the influencing factors on the $\mathrm{pH}$ stability of Yuxingcao injection. Two methods of accelerated tests were carried out in the experiments. The results showed that using Tween 80 as the solubilizer could significantly decrease the $\mathrm{pH}$ value of Yuxingcao injection after accelerated tests. There was no significant difference in the $\mathrm{pH}$ value after the accelerated tests when the other 6 factors varied, including the type of liquid processed, the dosage of activated carbon, heating temperature, reagents for $\mathrm{pH}$ adjustment, $\mathrm{pH}$ value range after adjustment, and sterilization conditions. In order to improve the quality stability of Yuxingcao injection, the quality of Tween 80 should be strictly controlled to minimize the change of $\mathrm{pH}$ value of Yuxingcao injection.
\end{abstract}

\section{Keywords}

Houttuyniae Herba, Chinese Medicine Injection, Quality Stability, Tween 80

\section{Introduction}

The Chinese medicine herb Yuxingcao is a fresh whole plant or dry above-ground part of Houttuynia cordata Thunb. It possesses the effects of clearing heat, detoxification, eliminating carbuncle and pus, and diuresis. Pharmacological researches have shown that Yuxingcao possesses antibacterial, antiviral, anti-inflammatory, immune enhancement, anti-allergic, anti-tumor effects [1] [2] [3] [4]. Yuxingcao 
injection is used for viral pneumonia, respiratory tract infection, viral enteritis, and acute urticaria of children. Quick onset and definite curative effects are the advantages of Yuxingcao injection [2].

Due to many adverse reactions, seven different injections made from Yuxingcao were temporarily prohibited of use by the China Food and Drug Administration in 2006. There are many reasons for the adverse reactions caused by Yuxingcao injection [5] [6] [7] [8], including fluctuations in the quality of injections, poor quality of excipients, unreasonable drug compatibility, excessive dosage, excessively rapid injection speed, and individual patient factors. Yuan et al. investigated the influences of drug compatibility of Yuxingcao injection and other injections [9]. However, less work is focusing on the pH stability of Yuxingcao injection.

This study investigates the factors that may affect the $\mathrm{pH}$ stability of Yuxingcao injection after formulation process. The results of this study will be beneficial to improve the quality control of Yuxingcao injection.

\section{Materials and Methods}

\subsection{Materials and Chemicals}

Hydroxypropyl-beta-cyclodextrin was purchased from Xi'an Deli Biochemical Co., Ltd. Hydrochloric acid and sodium hydroxide were purchased from Hengyang Kaixin Chemical Reagent Co., Ltd. Citric acid and sodium citrate were obtained from Hunan Huari Pharmaceutical Co., Ltd. Tween 80 was purchased from Nanjing Well Chemical Co., Ltd. Redistilled Yuxingcao aromatic water and purified water were obtained from Hunan Zhenqing Pharmaceutical Group Co., Ltd.

\subsection{Experimental Design}

A total of 7 factors were investigated using the $\mathrm{pH}$ value after an accelerated test as the evaluation index, including the type of liquid processed, solubilizer type, the dosage of activated carbon, heating temperature, reagents for $\mathrm{pH}$ adjustment, $\mathrm{pH}$ value range after adjustment, and sterilization conditions. There are 3 levels for each factor in the Taguchi designed experiments, as seen in Table 1. The orthogonal table $\mathrm{L}_{18}\left(3^{7}\right)$ was selected to arrange the experiments, as seen in Table 2 and Table 4. No repetition experiment was performed. Level 1 of the factor $\mathrm{E}$ was also used in Level 3 because there are only two different levels for factor E. The experiments were carried out according to the formulation method of Yuxingcao injection. The samples were prepared according to the combination of factors, potted into $10 \mathrm{ml}$ ampoules, and sterilized.

After sterilization, the samples was divided into two parts and treated with two different accelerated test methods. For Method A, ampoules was placed at $100^{\circ} \mathrm{C}$ for 6 hours, cooled to room temperature, refrigerated at $0^{\circ} \mathrm{C}-4^{\circ} \mathrm{C}$ for 12 hours, placed at $100^{\circ} \mathrm{C}$ for 6 hours, and cooled to room temperature. After that, $\mathrm{pH}$ value of the samples was measured, and compared with that measured before 
Table 1. Experimental factors and their levels.

\begin{tabular}{|c|c|c|c|c|}
\hline \multirow{2}{*}{ Factor No. } & \multirow{2}{*}{ Factor name } & \multicolumn{3}{|c|}{ Level } \\
\hline & & 1 & 2 & 3 \\
\hline Factor A & $\begin{array}{c}\text { The type of liquid } \\
\text { processed }\end{array}$ & Purified water & $\begin{array}{c}\text { Redistilled } \\
\text { aromatic water }\end{array}$ & $\begin{array}{c}\text { Redistilled } \\
\text { aromatic water } \\
\text { after refrigeration } \\
\text { and filtration }\end{array}$ \\
\hline Factor B & The type of solubilizer & $\begin{array}{c}\text { Tween } \\
80(0.25 \%)\end{array}$ & $\begin{array}{c}\text { Hydroxypropyl } \\
\beta \text {-cyclodextrin }(0.4 \%)\end{array}$ & $\begin{array}{c}\text { No solubilizer } \\
\text { added }\end{array}$ \\
\hline Factor C & $\begin{array}{l}\text { The dosage of } \\
\text { activated carbon }\end{array}$ & $0.05 \%$ & $\begin{array}{c}\text { no activated carbon } \\
\text { added }\end{array}$ & $0.10 \%$ \\
\hline Factor D & Heating temperature & $80^{\circ} \mathrm{C}, 5 \mathrm{~min}$ & $100^{\circ} \mathrm{C}, 5 \mathrm{~min}$ & $\begin{array}{c}\text { No heating } \\
\text { process }\end{array}$ \\
\hline Factor E & $\begin{array}{l}\text { Reagents for } \\
\text { pH adjustment }\end{array}$ & $\begin{array}{l}\text { Hydrochloric } \\
\text { acid/sodium } \\
\text { hydroxide }\end{array}$ & $\begin{array}{c}\text { Citric } \\
\text { acid/sodium } \\
\text { citrate }\end{array}$ & $\begin{array}{l}\text { Hydrochloric } \\
\text { acid/sodium } \\
\text { hydroxide }\end{array}$ \\
\hline Factor F & $\begin{array}{l}\mathrm{pH} \text { value range } \\
\text { after adjustment }\end{array}$ & $4.5-4.8$ & $5.5-5.8$ & $7.5-7.8$ \\
\hline Factor G & Sterilization conditions & $100^{\circ} \mathrm{C}, 30 \mathrm{~min}$ & $115^{\circ} \mathrm{C}, 30 \mathrm{~min}$ & $121^{\circ} \mathrm{C}, 13 \mathrm{~min}$ \\
\hline
\end{tabular}

Table 2. Results of the change of $\mathrm{pH}$ value after accelerated tests with method A.

\begin{tabular}{|c|c|c|c|c|c|c|c|c|c|c|}
\hline \multirow[b]{2}{*}{$\begin{array}{l}\text { Test } \\
\text { No. }\end{array}$} & \multicolumn{7}{|c|}{ Factors } & \multicolumn{3}{|c|}{ Results of $\mathrm{pH}$ value } \\
\hline & A & B & $\mathrm{C}$ & $\mathrm{D}$ & $\mathrm{E}$ & $\mathrm{F}$ & G & $\begin{array}{c}\text { Before } \\
\text { sterilization }\end{array}$ & $\begin{array}{l}\text { After the } \\
\text { accelerated } \\
\text { tests }\end{array}$ & $\begin{array}{l}\Delta \mathrm{pH} \\
\text { value }\end{array}$ \\
\hline 1 & 1 & 1 & 1 & 1 & 1 & 1 & 1 & 4.85 & 3.67 & -1.18 \\
\hline 2 & 1 & 2 & 2 & 2 & 2 & 2 & 2 & 5.60 & 6.44 & 0.84 \\
\hline 3 & 1 & 3 & 3 & 3 & 3 & 3 & 3 & 6.31 & 7.21 & 0.90 \\
\hline 4 & 2 & 1 & 1 & 2 & 2 & 3 & 3 & 7.28 & 7.38 & 0.10 \\
\hline 5 & 2 & 2 & 2 & 3 & 3 & 1 & 1 & 5.35 & 5.79 & 0.44 \\
\hline 6 & 2 & 3 & 3 & 1 & 1 & 2 & 2 & 5.91 & 6.59 & 0.68 \\
\hline 7 & 3 & 1 & 2 & 1 & 3 & 2 & 3 & 5.95 & 4.20 & -1.75 \\
\hline 8 & 3 & 2 & 3 & 2 & 1 & 3 & 1 & 6.39 & 6.79 & 0.40 \\
\hline 9 & 3 & 3 & 1 & 3 & 2 & 1 & 2 & 4.73 & 4.93 & 0.20 \\
\hline 10 & 1 & 1 & 3 & 3 & 2 & 2 & 1 & 5.47 & 4.20 & -1.27 \\
\hline 11 & 1 & 2 & 1 & 1 & 3 & 3 & 2 & 6.38 & 7.04 & 0.66 \\
\hline 12 & 1 & 3 & 2 & 2 & 1 & 1 & 3 & 5.17 & 6.28 & 1.11 \\
\hline 13 & 2 & 1 & 2 & 3 & 1 & 3 & 2 & 6.86 & 5.57 & -1.29 \\
\hline 14 & 2 & 2 & 3 & 1 & 2 & 1 & 3 & 4.83 & 5.34 & 0.51 \\
\hline 15 & 2 & 3 & 1 & 2 & 3 & 2 & 1 & 5.79 & 6.60 & 0.81 \\
\hline 16 & 3 & 1 & 3 & 2 & 3 & 1 & 2 & 4.97 & 3.85 & -1.12 \\
\hline 17 & 3 & 2 & 1 & 3 & 1 & 2 & 3 & 5.96 & 6.30 & 0.34 \\
\hline 18 & 3 & 3 & 2 & 1 & 2 & 3 & 1 & 7.14 & 7.97 & 0.83 \\
\hline $\bar{K}_{1}$ & 0.177 & -1.085 & 0.155 & -0.042 & 0.010 & -0.007 & 0.005 & & & \\
\hline $\bar{K}_{2}$ & 0.208 & 0.532 & 0.030 & 0.357 & 0.202 & -0.058 & -0.005 & & & \\
\hline $\bar{K}_{3}$ & -0.183 & 0.755 & 0.017 & -0.113 & -0.010 & 0.267 & 0.202 & & & \\
\hline$R$ & 0.391 & 1.840 & 0.138 & 0.470 & 0.212 & 0.325 & 0.207 & & & \\
\hline
\end{tabular}


accelerated tests. For Method B, ampoules were stored at $60^{\circ} \mathrm{C}$ for 10 days. After that, $\mathrm{pH}$ value of the sample was measured on the 10th day, and calculated the $\mathrm{pH}$ value change amount on that of Day 0 . All the experiments were carried out during 2009-2010 in the lab of Hunan Zhenqing Pharmaceutical Group Co., Ltd., Huaihua, Hunan province of China.

\subsection{Preparation of Yuxingcao Injection}

A volume of $500 \mathrm{ml}$ of Yuxingcao redistilled aromatic water was used in the experiments of Table 2 or Table 3 for experiments No. 4 - 9 and No. 13 - 18. According to experimental conditions, some aromatic water was filtered after refrigerating at $0^{\circ} \mathrm{C}-4^{\circ} \mathrm{C}$. The solubilizer was then added to the filtrate. If the aromatic water need not to be filtered, the solubilizer was added to it directly. Then the aromatic water was treated with activated carbon or heating. The $\mathrm{pH}$

Table 3. Results of the change of $\mathrm{pH}$ value after accelerated tests with method $\mathrm{B}$.

\begin{tabular}{|c|c|c|c|c|c|c|c|c|c|c|}
\hline \multirow[b]{2}{*}{$\begin{array}{l}\text { Test } \\
\text { No. }\end{array}$} & \multicolumn{7}{|c|}{ Factors } & \multicolumn{3}{|c|}{ Results of $\mathrm{pH}$ value } \\
\hline & A & B & $\mathrm{C}$ & $\mathrm{D}$ & $\mathrm{E}$ & $\mathrm{F}$ & G & $\begin{array}{c}\text { Before } \\
\text { sterilization }\end{array}$ & $\begin{array}{c}\text { After the } \\
\text { accelerated } \\
\text { tests }\end{array}$ & $\begin{array}{l}\Delta \mathrm{pH} \\
\text { value }\end{array}$ \\
\hline 1 & 1 & 1 & 1 & 1 & 1 & 1 & 1 & 4.85 & 3.82 & -1.03 \\
\hline 2 & 1 & 2 & 2 & 2 & 2 & 2 & 2 & 5.60 & 6.24 & 0.64 \\
\hline 3 & 1 & 3 & 3 & 3 & 3 & 3 & 3 & 6.31 & 6.78 & 0.47 \\
\hline 4 & 2 & 1 & 1 & 2 & 2 & 3 & 3 & 7.28 & 7.48 & 0.2 \\
\hline 5 & 2 & 2 & 2 & 3 & 3 & 1 & 1 & 5.35 & 5.83 & 0.48 \\
\hline 6 & 2 & 3 & 3 & 1 & 1 & 2 & 2 & 5.91 & 6.37 & 0.46 \\
\hline 7 & 3 & 1 & 2 & 1 & 3 & 2 & 3 & 5.95 & 4.26 & -1.69 \\
\hline 8 & 3 & 2 & 3 & 2 & 1 & 3 & 1 & 6.39 & 6.63 & 0.24 \\
\hline 9 & 3 & 3 & 1 & 3 & 2 & 1 & 2 & 4.73 & 4.96 & 0.23 \\
\hline 10 & 1 & 1 & 3 & 3 & 2 & 2 & 1 & 5.47 & 4.63 & -0.84 \\
\hline 11 & 1 & 2 & 1 & 1 & 3 & 3 & 2 & 6.38 & 6.76 & 0.38 \\
\hline 12 & 1 & 3 & 2 & 2 & 1 & 1 & 3 & 5.17 & 6.02 & 0.85 \\
\hline 13 & 2 & 1 & 2 & 3 & 1 & 3 & 2 & 6.86 & 5.49 & -1.37 \\
\hline 14 & 2 & 2 & 3 & 1 & 2 & 1 & 3 & 4.83 & 5.37 & 0.54 \\
\hline 15 & 2 & 3 & 1 & 2 & 3 & 2 & 1 & 5.79 & 6.13 & 0.34 \\
\hline 16 & 3 & 1 & 3 & 2 & 3 & 1 & 2 & 4.97 & 4.03 & -0.94 \\
\hline 17 & 3 & 2 & 1 & 3 & 1 & 2 & 3 & 5.96 & 6.21 & 0.25 \\
\hline 18 & 3 & 3 & 2 & 1 & 2 & 3 & 1 & 7.14 & 7.78 & 0.64 \\
\hline $\bar{K}_{1}$ & 0.078 & -0.945 & 0.062 & -0.117 & -0.100 & 0.022 & -0.028 & & & \\
\hline $\bar{K}_{2}$ & 0.108 & 0.422 & -0.075 & 0.222 & 0.235 & -0.140 & -0.100 & & & \\
\hline $\bar{K}_{3}$ & -0.212 & 0.498 & -0.012 & -0.130 & -0.160 & 0.093 & 0.103 & & & \\
\hline$R$ & 0.320 & 1.443 & 0.137 & 0.352 & 0.395 & 0.233 & 0.203 & & & \\
\hline
\end{tabular}


value of the aromatic water was adjusted. After that, the aromatic water was filtered, potted, and sterilized. Purified water was used for Experiments 1 - 3 in Table 2, and 10 - 12 in Table 3. Purified water was added solubilizer, and then it was treated with activated carbon or heating. The $\mathrm{pH}$ value of the purified water was adjusted. After that, the purified water was filtered, potted, and sterilized.

\section{Results and Discussions}

\subsection{Results and Analysis of Accelerated Tests with Method A}

In the accelerated tests with method $\mathrm{A}$, the temperature was changed repeatedly. After that, the change of $\mathrm{pH}$ value was measured. The results are shown in Table 2. It can be seen from the table that the $\mathrm{pH}$ value of most samples increased after the accelerated tests. The increase can exceed 1.1. But the $\mathrm{pH}$ value of a few samples decreased significantly.

The comprehensive average $(\bar{K})$ and range of change of $\mathrm{pH}$ value $(R)$ are shown in Table 2. The most extreme difference of range was caused by factor $\mathrm{B}$, which meant that the choice of solubilizer had the greatest impact on the change of $\mathrm{pH}$ value after the accelerated tests. The other ranges were all less than 0.5. The results of the analysis of variance are shown in Table 4. Only factor B has a statistically significant influence, and the $\mathrm{p}$ value was less than 0.01 . Considering the change of the comprehensive average, it can be seen that using Tween 80 as the solubilizer significantly reduced the $\mathrm{pH}$ value after the accelerated tests.

\subsection{Results and Analysis of Accelerated Tests with Method B}

In the accelerated tests with method $\mathrm{B}$, the samples were placed at $60^{\circ} \mathrm{C}$ for a long time. After that, the change of $\mathrm{pH}$ value was measured. The results are shown in Table 3. The $\mathrm{pH}$ value of most samples increased after the accelerated tests. The increase was less than 0.9 . The $\mathrm{pH}$ value of a few samples dropped significantly.

Table 4. ANOVA results of accelerated tests with method $A^{*}$.

\begin{tabular}{ccccccc}
\hline Factor & $\begin{array}{c}\text { Sum of squared } \\
\text { deviations }\end{array}$ & $\begin{array}{c}\text { Degrees of } \\
\text { freedom }\end{array}$ & $\begin{array}{c}\text { Mean } \\
\text { square }\end{array}$ & F value & p value & $\begin{array}{c}\text { Statistical } \\
\text { significance }\end{array}$ \\
\hline B & 0.568 & 2 & 0.284 & 1.788 & $>0.1$ & No \\
C & 12.098 & 2 & 6.049 & 38.075 & $<0.01$ & Yes \\
D & 0.070 & 2 & 0.035 & 0.220 & $>0.1$ & No \\
E & 0.769 & 2 & 0.385 & 2.421 & $>0.1$ & No \\
$F$ & 0.164 & 2 & 0.082 & 0.516 & $>0.1$ & No \\
F & 0.366 & 2 & 0.183 & 1.152 & $>0.1$ & No \\
Error & 0.163 & 2 & 0.081 & 0.513 & $>0.1$ & No \\
${ }^{*} \mathrm{~F}_{0.01(2.3)}=30.82, \mathrm{~F}_{0.05(2.3)}=9.55, \mathrm{~F}_{0.1(2.3)}=5.46$. & & & & &
\end{tabular}


The comprehensive average and range of change of $\mathrm{pH}$ value are shown in Table 3. The most extreme difference of range was still caused by factor B. The other ranges were all less than 0.4 . The results of the analysis of variance are shown in Table 5. Only factor B has a statistically significant influence, and the $\mathrm{P}$ value was less than 0.05 . Considering the change of the comprehensive average, it can be concluded that using Tween 80 as the solubilizer significantly reduced the $\mathrm{pH}$ value after the accelerated tests.

\section{Discussion}

$\mathrm{Xu}$ compared Tween 80 from different manufacturers, and found that the $\mathrm{pH}$ value of the aqueous solution of Tween 80 decreased after heating [10]. It was speculated that it was caused by the hydrolysis of the ester bond of Tween 80 [10]. Tween 80 can cause allergic reactions has been confirmed by different researchers [11] [12]. Yi et al. pointed out that the main manufacturers of Yuxingcao Injection had reduced the concentration of Tween 80 , and used injection grade Tween 80 [6]. These acts reduced the occurrence of allergic reactions [6]. Honemann et al. explained the relationship between hydrolysis of Tween 80 and allergic reactions [13]. Long chain free fatty acids will form in the hydrolysis of Tween 80 [13]. The low solubility of long chain free fatty acids in aqueous solution results in the formation of visible and subvisible particulates, which are considered as a cause for allergic reactions [13]. This study confirms that Tween 80 also has a greater impact on the $\mathrm{pH}$ value of the injection. This phenomenon is probably caused by the formation of free fatty acids. Therefore, the quality control of Tween 80 should be more stringent.

Although this study found that Tween 80 has a greater impact on the $\mathrm{pH}$ value of the formulation, it is not enough to focus on changes of the $\mathrm{pH}$ value in terms of formulation quality control. Zeng and Li carried out a long-term stability experiment of Yuxingcao injection and found that the content of houttuynin and mehtyl-nnonylketone changed little [14]. The types of main volatile components

Table 5. ANOVA results of accelerated tests with method B*.

\begin{tabular}{ccccccc}
\hline Factor & $\begin{array}{c}\text { Sum of squared } \\
\text { deviations }\end{array}$ & $\begin{array}{c}\text { Degrees of } \\
\text { freedom }\end{array}$ & $\begin{array}{c}\text { Mean } \\
\text { square }\end{array}$ & F value & p value & $\begin{array}{c}\text { Statistical } \\
\text { significance }\end{array}$ \\
\hline A & 0.375 & 2 & 0.187 & 0.818 & $>0.1$ & No \\
B & 7.914 & 2 & 3.957 & 17.279 & $<0.05$ & Yes \\
C & 0.056 & 2 & 0.028 & 0.123 & $>0.1$ & No \\
D & 0.477 & 2 & 0.238 & 1.041 & $>0.1$ & No \\
E & 0.544 & 2 & 0.272 & 1.187 & $>0.1$ & No \\
F & 0.171 & 2 & 0.086 & 0.374 & $>0.1$ & No \\
G & 0.128 & 2 & 0.064 & 0.279 & $>0.1$ & No \\
Error & 0.687 & 3 & 0.229 & & & \\
\hline
\end{tabular}

${ }^{*} \mathrm{~F}_{0.01(2.3)}=30.82, \mathrm{~F}_{0.05(2.3)}=9.55, \mathrm{~F}_{0.1(2.3)}=5.46$. 
and their relative contents neither changed significantly [14]. Hao et al. suggested that the quality control of Yuxingcao injection should pay more attention to the quality control of Houttuynia herbal material, including avoiding the use of miscible products, performing standardized planting, selecting good varieties, improving the quality standards of Houttuynia, and strengthening heavy metal detection [15].

\section{Conclusion}

This study investigated the influence of many formulation conditions, including the type of liquid processed, solubilizer type, the dosage of activated carbon, heating temperature, reagents for $\mathrm{pH}$ adjustment, $\mathrm{pH}$ value range after adjustment, and sterilization conditions, on the decrease of $\mathrm{pH}$ value of Yuxingcao injection. It is found that when Tween 80 was used as the solubilizer, the $\mathrm{pH}$ value significantly decreased after accelerated tests. The influence of other factors on $\mathrm{pH}$ value is not significant. Considering that Tween 80 is also one of the causes of adverse reactions, high-quality Tween 80 should be used for the production of Yuxingcao injection.

\section{Conflicts of Interest}

The authors declare no conflicts of interest regarding the publication of this paper.

\section{References}

[1] Wu, P.Y., Xu, L.Y. and Tao, J.S. (2006) Research Progress of Herba Houttuyniae. Shanghai Journal of Traditional Chinese Medicine, 40, 62-64.

[2] Qin, M.L. (2015) Application of Herba Houttuyniae Were Reviewed. Popular Science \& Technology, 17, 105-107.

[3] Chiow, K.H., Phoon, M.C., Putti, T., Tan, B.K.H. and Chow, V.T. (2016) Evaluation of Antiviral Activities of Houttuynia cordata Thunb. Extract, Quercetin, Quercetrin and Cinanserin on Murine Coronavirus and Dengue Virus Infection. Asian Pacific Journal of Tropical Medicine, 9, 1-7. https://doi.org/10.1016/j.apjtm.2015.12.002

[4] Lu, H.M., Liang, Y.Z., Yi, L.Z. and Wu, X.J. (2006) Anti-Inflammatory Effect of Houttuynia cordata Injection. Journal of Ethnopharmacology, 104, 245-249. https://doi.org/10.1016/j.jep.2005.09.012

[5] Zhang, M.Y. and Li, L.D. (2010) Cause Analysis and Solutions of Adverse Reactions of Yuxingcao Injection. Pharmacology and Clinics of Chinese Materia Medica, 26, 77-81.

[6] Yi, Y., et al. (2015) Evaluation and Study of Pseudo-Allergic Reactions of Three Kinds of Traditional Chinese Medicine Injections and Its Mechanisms. China Journal of Chinese Materia Medica, 40, 2711-2716.

[7] Wang, Z., Xie, Y. and Wang, Y. (2011) Study on Adverse Drug Reaction in Yuixngcao Injection Literatures. China Journal of Chinese Materia Medica, 36, 2862-2865.

[8] Wang, L., et al. (2010) Adverse Events to Houttuynia Injection: A Systematic Review. Journal of Evidence-Based Medicine, 3, 168-176.

https://doi.org/10.1111/j.1756-5391.2010.01091.x 
[9] Yuan, H.Y., Luo, D.F. and Liu, H.W. (2010) Investigation on the Compatibility and Stability of Yuxingcao Injection with Three Kinds of Injections. Journal of Emergency in Traditional Chinese Medicine, 19, 1920-1921.

[10] Xu, F. (1989) The Influences of Temperature on the pH Value of Tween 80 Solution. Chinese Traditional Patent Medicine, 7, 46.

[11] Yi, W.U., et al. (2007) Studies on the Reason of Severe Adverse Reaction (ADR) in Clinics Induced by Yuxingcao Injections (I). Chinese Journal of Pharmaceutical Analysis, 27, 782-785.

[12] Sun, W.-W., Li, Y.-K. and Zhang, J.-Y. (2011) Anaphylactoid Reactions Inducing Effect of Polysorbate 80 and Polysorbate 80 Contained Houttuynia cordata Injection on Beagle. Chinese Journal of Integrated Traditional and Western Medicine, 31, 90-93.

[13] Honemann, M.N., Wendler, J., Graf, T., Bathke, A. and Bell, C.H. (2019) Monitoring Polysorbate Hydrolysis in Biopharmaceuticals Using a QC-Ready Free Fatty Acid Quantification Method. Journal of Chromatography B Analytical Technologies in the Biomedical and Life Sciences, 1116, 1-8. https://doi.org/10.1016/j.jchromb.2019.03.030

[14] Zeng, M.G. and Li, Y. (2014) Research on the Quality Stability of Yuxingcao Injection. Global Traditional Chinese Medicine, 7, 200-203.

[15] Hao, L.J., Liang, A.H. and Song, J.Y. (2020) Research Progress on the Raw Material Resources and Quality Control of Houttuynia cordata Injection. World Journal of Traditional Chinese Medicine, 15, 657-662. 